\title{
KOMPETENSI INTERNASIONAL AKUNTANSI FORENSIK MAHASISWA AKUNTANSI DI BEBERAPA UNIVERSITAS DI SEMARANG
}

\author{
Muhammad Rizky Garuda Nusantara Bachrul Zakir Hamzah \\ Heri Yanto \\ yanto63@yahoo.com \\ (Universitas Negeri Semarang)
}

\begin{abstract}
In the era of globalization accounting graduates equipped with international competencies would have better access to find jobs in other countries. The roles of universities in preparing their accounting graduates are pivotal. The objectives of the study is to identify the contributions of univesities in preparing their graduates to master international competencies of forensic accounting $(K I A F)$. The population of the study are final-year accounting students of all universities in Semarang. By employing multi-stage smpling technique, the study collected 218 data. Moreover, the study used a five-point-Likert-type scale for both variables of accounting course enggagement (KMPA) and KIAF. KMPA was the proxy for measuring the process of accounting education at the university.Descriptive, correlation, and regression analyses were employed to analyze data. Almost all factors of KMPA significantly correlate with factors of KIAF. Canonical analysis shows that covariates of KMPA factors mostly correlate with canonical variable. Almost all factors of KMPA have significant contributions in building students' competencies of forensic accounting Universities should improve the education processes of accounting to increase the KIAF. Since, the KIAF was measured using students' perceptions, future research should focus on the impacts of KMPA on real competency of forensic accounting.
\end{abstract}

\section{Keywords: Competency of Forensic Accounting, Accounting Course Engagement}

\section{PENDAHULUAN}

Kecurangan telah menjadi permasalahan yang begitu besar dan berat, sehingga menjadi salah satu perhatian utama dunia global (Gbegi \& Adebisi, 2014) serta menjadi isu diskusi dalam bidang akademik dan non akademik (Ajao et. al, 2013). Kasus Enron, WorldCom, dan Parmalat hanya beberapa contoh dari skandal dan kecurangan akuntansi yang begitu terkenal di dunia akuntansi (Bhasin, 2013). Sementara itu di Indonesia Komisi Pemberantasan Korupsi (KPK) juga telah menyelesaikan berbagai kasus kecurangan yang hingga Desember 2013 sebanyak 1,1 triliun rupiah lebih telah dimasukkan ke kas negara dalam bentuk Pendapatan Negara Bukan Pajak (PNBP) dari penanganan perkara (KPK, 2013).

Berbagai kasus kecurangan telah menjadi sebuah alasan yang kuat bahwa akuntansi forensik merupakan ilmu sangat penting di dunia internasional maupun nasional dan menjadi sebuah ilmu yang krusial untuk mengungkap berbagai kecurangan dalam dunia keuangan (Bhasin, 2007). Dalam hal ini perguruan tinggi yang menghasilkan lulusan akuntansi tentu diharuskan mengembangkan 
kompetensi dasar akuntan forensik pada mahasiswa akuntansi agar lulusan akuntansi tersebut siap menjadi seorang akuntan forensik yang berkualitas. Akan tetapi, masih banyak keterampilan dan atribut yang dibutuhkan lulusan akuntansi tidak dikembangkan pada tingkat perguruan tinggi (Kavanagh \& Drennan, 2008). Keadaan ini sejalan dengan fakta yang terjadi pada perguruan tinggi di Indonesia yang belum mengembangkan kompetensi akuntansi yang sesuai dengan pengguna jasa akuntansi (Putri \& Harto, 2012).

Ada tiga isu akuntansi yang harus disesuaikan dengan pendidikan di Indonesia yaitu globalisasi ekonomi, investasi asing, dan penerapan standar akuntansi baru (Yanto, Mula, \& Kavanagh, 2010). Globalisasi memungkinkan pergerakan tenaga kerja, tehnologi, modal, barang dan jasa antar negara (Krueger, 2002), bahkan dapat diikuti dengan berkembangnya kasus kecurangan pada berbagai sektor. Pada dasarnya kondisi ini semakin menuntut peningkatan kualitas kompetensi lulusan akuntansi untuk menjadi seorang akuntan yang berstandar kompetensi internasional serta mampu memberikan jasa profesionalnya dengan baik (Putri \& Harto, 2012).

AICPA telah menentukan standar kompetensi yang harus dimiliki seorang akuntan forensik dari survei yang dilaksanakannya sebagai bentuk pencegahan dan penanggulangan berbagai kasus kecurang (Davis, Farrell, \& Ogilby, 2010). Penerapan standar kompetensi akuntan forensik tersebut harus diharmonikan dengan kompetensi akuntansi yang ada di Indonesia. Dengan kata lain, kompetensi ini harus diselaraskan dengan pendidikan akuntansi yang berlaku di Indonesia. Hal ini disebabkan standar akuntansi dari setiap negara memiliki perbedaan karena berbagai faktor seperti kondisi ekonomi, ideologi ekonomi yang dianut, kondisi politik dan sosial setiap negara (Sadjiarto, 1999).

Upaya dalam pembentukan seorang akuntan forensik yang efektif dan berstandar kompetensi internasional diperlukan peran yang sangat besar untuk mengharmonikan antara pendidikan akuntansi dengan praktik akuntansi (Yanto, 2012). Hal ini didukung oleh AICPA yang juga telah menentukan kompetensi minimum lulusan universitas untuk masuk ke dalam profesi akuntansi (Mula, 2009) dan juga telah menetapkan standar kompetensi yang harus dimiliki seorang akuntan forensik (Davis et al., 2010). Hal ini didukung juga oleh pernyataan Christiawan (2002) bahwa kompetensi berkaitan dengan pendidikan dan pengalaman yang memadai. Hal ini diharapakan mampu untuk mendukung pembentukan kompetensi internasional akuntansi forensik kepada para lulusan akuntansi.

Pembentukan kompetensi internasional akuntansi forensik di universitas dalam penelitian ini menggunakan Kelibatan Mahasiswa dalam Pembelajaran Akuntansi (KMPA) sebagai proksi dari proses perkuliahan. KMPA adalah bentuk lain dari Student Engagement yang sudah banyak digunakan di negara maju. AUSSE dan NSSE yang telah menggunakan student engagement untuk mengukur proses belajar mengajar yang terjadi di perguruan tinggi (Yanto, Mula, \& Kavanagh, 2011b). Student Engagement digunakan untuk mengukur prses pendidikan di perguruan tinggi secara umum, sehingga kemungkinan kurang akurat bila digunakan untuk mengukur pendidikan yang terjadi di bidang akuntansi. Oleh karena itu, penelitian ini menggunakan KMPA untuk mengukur kualitas proses belajar mengajar matakuliah akuntansi. Maka dari itu, dalam 
penelitian ini KMPA akan diuji hubungannya dengan kompetensi internasional akuntansi forensik mahasiswa akuntansi pada beberapa universitas di Semarang.

Pendidikan akuntansi di beberapa universitas di Semarang terus mengalami perubahan dan perbaikan. Di kota ini terdapat dua universitas negeri dan sepuluh universitas swasta dengan tiga universitas dengan jurusan akuntansi berakreditasi $\mathrm{A}$, enam universitas dengan jurusan akuntansi berakreditasi $\mathrm{B}$, dan tiga universitas dengan jurusan akuntansi berakreditasi C (DIKTI, 2014). Akreditasi ini bisa menjadi cermin kualitas pendidikan pada jurusan akuntansi pada universitas di Semarang.

\section{KAJIAN PUSTAKA}

Involvement Theory yang dikembangkan oleh Astin (1999) mendefinisikan involvement sebagai kelibatan mahasiswa, besarnya energi fisik, dan kekuatan psikologis siswa yang digunakan untuk memperoleh pengalaman akademis. Dengan kata lain, jika kelibatan mahasiswa, besarnya energi fisik, dan kekuatan psikologis mahasiswa digunakan secara optimal, maka mahasiswa tersebut akan mendapatkan pengalaman akademis yang baik. Perkembangan akademis mahasiswa berkaitan erat dengan kelibatan mahasiswa dengan temannya, dosen, dan program akademisnya (Norwani, 2005). Pendapat tersebut menunjukkan bahwa perkembangan akademis mahasiswa dipengaruhi oleh kelibatan mahasiswa, besarnya energi fisik, dan kekuatan psikologis yang didukung oleh interaksi yang bersinergi dengan teman, dosen, dan program akademisnya. Selain itu, Yanto (2012) mengungkapkan juga bahwa kualitas akademis mahasiswa tergantung pada kelibatannya dalam hal akademis maupun non akademis.

Secara luas, akuntansi forensik dapat diartikan sebagai campuran akuntansi, keuangan, hukum, komputerisasi, etika, dan kriminologi dimana akuntansi forensik ini fokus pada pencegahan dan deteksi terjadinya penipuan keuangan dan melakukan penyelidikan yang bertujuan untuk membantu dalam mempermudah menentukan tersangka (Mehta \& Mathur, 2007). AICPA mendefinisikan akuntansi forensik sebagai penerapan prinsip akuntansi, teori, dan disiplin untuk mengungkap fakta atau hipotesis isu-isu di dalam sengketa hukum dan merupakan cabang akuntansi yang mencakup setiap pengetahuan tentang akuntansi (Davis et al., 2010). Kemudian Tuanakotta (2013) mendefinisikan akuntansi forensik adalah penerapan disiplin akuntansi dalam arti luas, termasuk auditing pada masalah hukum untuk penyelesaian hukum di luar pengadilan.

Kecurangan (fraud) merupakan tindakan dari seseorang yang menginginkan keuntungan lebih dengan cara memberikan laporan palsu kepada pihak-pihak lain, tindakan penipuan ini dapat berupa tindakan yang tidak jujur, tipuan, dan kelicikan yang dilakukan dalam menyajikan laporan keuangan yang belum diaudit (Singleton \& Singleton, 2006). Menurut ACFE (2012) kecurangan merupakan tindakan penipuan yang bertujuan untuk mendapatkan keuntungan pribadi yang dapat membuat kerugian bagi pihak lain baik dalam bentuk tunai atau barang atau dengan cara menghindari sebuah kewajiban yang harus dipenuhi. Kemudian menurut AICPA (2012) kecurangan merupakan tindakan yang sengaja dilakukan oleh satu atau lebih individu yang memiliki kepentingan dalam sebuah instansi atau perusahaan yang mengakibatkan salah saji dalam laporan keuangan.

IFAC (2010) mendifinisikan bahwa kompetensi merupakan kemampuan untuk bekerja berdasarkan peran yang sesuai dengan standar yang telah ditetapkan 
yang mengacu pada lingkungan kerja yang tersedia. Kompetensi dari mahasiswa akuntansi dipengaruhi banyak hal, salah satunya adalah proses pembelajaran yang diberikan perguruan tinggi kepada mahasiswa (Yanto, 2012). Hardern (1995) mengemukakan bahwa institusi pendidikan memberikan pengaruh yang sangat penting untuk membangun kemampuan pribadi, komunikasi, kemampuan sosial setiap siswa dan selain itu juga untuk memastikan lulusan akuntansi dapat sesuai dengan ekspetasi dari kebutuhan para klien. Oleh karerna itu, mahasiswa jurusan akuntansi haruslah diberikan proses pembelajaran yang berkualitas tentang akuntansi forensik guna menjadi seorang lulusan akuntansi yang memiliki kompetensi internasional akuntansi forensik.

Natriello (1984) dalam Appleton et. al. (2008) mendefinisikan student engagement sebagai partisipasi siswa dalam kegiatan yang menjadi bagian dari program sekolah. Kemudian Newmann et al. (1992) dalam Appleton et al. (2008) mendefinisikan Student engagement sebagai curahan psikologis dan usaha yang dikerahkan siswa terhadap pembelajaran, pemahaman atau penguasaan suatu pengetahuan, keterampilan atau karya yang menjadi tujuan dari kegiatan akademis. Penelitian sebelumnya yang dilakukan oleh Yanto et al. (2010) dan Yanto (2012) mengemukakan bahwa student engagement (SE) secara signifikan berkorelasi dengan kompetensi intenasional lulusan akuntansi, sementara itu Yanto, Mula, and Kavanagh (2011a) dan Yanto et al. (2011b) dalam penelitiannya yang lainnya mengemukakan kembali bahwa student engagement (SE) signifikan berkorelasi dengan kompetensi lulusan akuntansi. Sejalan dengan penelitian dan pengertian yang ada, maka dapat dilihat bahwa peran pihak universitas juga sangatlah penting untuk mendukung kelibatan mahasiswa dalam proses pembelajaran.

Kompetensi akuntansi forensik berstandar internasional ini diukur dengan menggunakan indikator yang sesuai dengan standar kompetensi dari seorang akuntan forensik yang telah ditetapkan oleh AICPA. Adapun kompetensi akuntan forensik ditetapkan AICPA yang dikemukakan oleh Davis et al. (2010) akan digunakan sebagai indikator.

Tabel 1. Kompetensi Internasional Akuntansi Forensik

\begin{tabular}{|c|c|c|}
\hline $\begin{array}{l}\text { Essential Traits } \\
\text { and } \\
\text { Characteristics }\end{array}$ & Core Skills & Enhanced Skills \\
\hline Analytical & Critical/Strategic Thinker & $\begin{array}{l}\text { Analyze And Interpret } \\
\text { Financial Statements and } \\
\text { Information }\end{array}$ \\
\hline Inquisitive & $\begin{array}{l}\text { Effective Written } \\
\text { Communicator }\end{array}$ & Interview Skill \\
\hline $\begin{array}{l}\text { Detail- } \\
\text { Oriented }\end{array}$ & $\begin{array}{l}\text { Effective Oral } \\
\text { Communicator }\end{array}$ & Fraud Detection \\
\hline Ethical & Investigative Ability & Testifying \\
\hline Skepticism & Investigative Intuitiveness & $\begin{array}{l}\text { General Knowledge of Rules } \\
\text { of Evidence and Civil } \\
\text { Procedure }\end{array}$ \\
\hline
\end{tabular}

Source: Davis et. al (2010) 
Indikator tersbut merupakan hasil identifikasi kompetensi yang diperlukan untuk menjadi seorang akuntan forensik yang disampaikan oleh para akuntan forensik. Davis et al. (2010) mengklasifikasikan kompetensi forensik ke dalam tiga klasifikasi yaitu Essential Traits and Characteristics (ETC), Core Skills (CS), dan Enhance Skills (ES). Namun, sejauh ini belum ada pengembangan alat ukur berbentuk Likert. Oleh karena itu, penelitian ini akan membuat alat ukur berdasarkan persepsi mahasiswa akuntansi.

Kelibatan mahasiswa atau student engagement terdiri dari beberapa faktor yaitu tantangan akademik (TA), belajar aktif (BA), hubungan dosen dengan mahasiswa (HDM), pengayaan pengalaman (PP), dan lingkungan belajar (LB), serta kuliah yang berhubungan dengan kerja (AUSSE, 2010; AUSSE, 2011; NSSE,2009). Student engagement di atas masih merupakan proxy pengukuran proses belajar mengajar secara umum yang berlangsung di universitas. Penelitian ini menggunakan student engagement yang lebih sempit yaitu kelibatan mahasiswa pada pembalajaran akuntansi (KMPA). Mengacu pada faktor yang telah dikembangkan oleh NSSE (2009), penelitian ini berusaha memotret proses pembelajaran akuntansi di universitas. AUSSE (2010) dalam surveinya mengenai student engagement mengungkapkan bahwa ruang lingkup dari tantangan akademik adalah sejauh mana harapan dan penilaian terhadap tantangan yang didapat mahasiswa dalam proses pembelajaran. Tantangan akademik yang ada dalam perguruan tinggi juga dapat menciptakan budaya etik yang kuat, dimana perguruan tinggi dapat menghasilkan lulusan yang memiliki karakter, etika serta moral yang baik dan siap dalam dunia kerja secara professional (Procario-Foley and Bean, 2002 di dalam Weber, 2006; dan Arokiasamy et al., 2009). Involvement theory pun dapat menjelaskan bahwa kelibatan mahasiswa dalam proses pendidikan dipengaruhi oleh tantangan akademik yang dapat berupa tuntutan dosen untuk mencapai kompetensi pendidikan yang diharapkan. AUSSE (2010) juga mengemukakan bahwa tantangan akademik berpengaruh signifikan terhadap nilai rata-rata secara keseluruhan pada mahasiswa. Selanjutnya (Yanto et al., 2011b) secara lebih spesifik mengemukakan bahwa tantangan akademik berkorelasi signifikan dengan seluruh faktor kompetensi akuntansi pada mahasiswa akuntansi.

Kelibatan mahasiswa dalam proses akademik akan membuat mahasiswa lebih banyak belajar dan berfikir mengenai apa yang telah mereka pelajari (Kuh, 2009). Mahasiswa dapat berkompetisi dengan mahasiswa lainnya, atau individualistis untuk mencapai tujuannya, dan atau bekerja sama dengan saling memberikan perhatian satu sama lain (Mutmainah, 2008). Phipps, Kas, dan Higgins (2001) mengungkapkan bahwa belajar aktif (BA) akan meningkatkan prestasi, hubungan interpersonal yang lebih positif, dan self-esteem yang lebih tinggi dibanding upaya kompetitif dan individualistis. Involvement theory dapat menjelaskan bahwa sistem pembelajaran yang digunakan dalam perkuliahan berperan sebagai pendukung kelibatan mahasiswa untuk terlibat aktif dalam proses perkuliahan untuk membentuk kompetensi internasional akuntansi forensik lulusan akuntansi.

AUSSE (2010) menyatakan bahwa pembelajaran kooperatif merupakan bagian dari active learning. Dengan kata lain pembelajaran kooperatif merupakan metode pembelajaran yang mendukung terciptanya pembelajaran yang aktif. Kemudian AUSSE (2010) juga mengemukakan bahwa belajar aktif berpengaruh 
signifikan terhadap nilai rata-rata secara keseluruhan pada mahasiswa dan (Yanto et al., 2011b) secara lebih spesifik mengemukakan bahwa belajar aktif berkorelasi dengan seluruh faktor kompetensi internasional akuntansi. Akan tetapi hanya belajar aktif yang secara signifikan berpengaruh positif terhadap personal competency. Dengan demikian, bisa disimpulkan bahwa pembelajaran kooperatif memberikan kontribusi dalam membangun komptensi internasional akuntansi forensik (KIAF).

Penelitian yang dilakukan di University of Victoria menyimpulkan bahwa hubungan dosen dengan mahasiswa akan mempengaruhi kompetensi mahasiswa (UVIC, 2007). Hubungan dosen mahasiswa dapat sebagai indikator atmosfer akademik. Ketika atmosfer akademik baik maka hal tersebut memungkinkan mahasiswa dapat selalu aktif di dalam proses perkuliahan dan mendorong dosen untuk merancang struktur pembelajaran yang baik guna meningkatkan peran dosen sebagai fasilitator (Kumara \& Harsono, 2005). Involvement theory menunjukkan bahwa mahasiswa dalam proses pembelajaran baik di dalam maupun di luar perkuliahan dipengaruhi juga oleh interkasi yang terjalin antara mahasiswa dengan dosen. Etika, pola pikir, dan sikap lainnya dari seorang dosen akan ditransfer kepada mahasiswanya.

AUSSE (2010) mengemukakan bahwa hubungan dosen dan mahasiswa berpengaruh signifikan terhadap nilai rata-rata secara keseluruhan pada mahasiswa. Hambleton (2008) mengemukakan bahwa hubungan dosen mahasiswa merupakan faktor penting dalam pembentukan output pendidikan berupa kompetensi yang dicapai mahasiswa. Selanjutnya Yanto et al. (2011b) secara lebih spesifik mengemukakan hubungan dosen mahasiswa berkorelasi terhadap seluruh faktor kompetensi internasional akuntansi. Namun demikian, variabel ini hanya berpengaruh signifikan terhadap broad-business perspective competency.

AUSSE (2011) menyatakan bahwa pengayaan pengalaman berkaitan dengan tingkat partisipasi mahasiswa dalam menjalankan aktivitasnya di universitas. Sejalan dengan hal tersebut NSSE (2009) menyatakan bahwa pengayaan pengalaman berkaitan dengan kesempatan belajar yang tersedia baik di dalam maupun di dalam kelas. Berbagai organisasi di universtas dapat menjadi sarana pengembangan kemampuan soft skills mahasiswa yang berguna dalam pencapaian kompetensi yang diharapkan dari proses perkuliahan. Selanjutnya involvement theory menjelaskan bahwa soft skill yang terbentuk dari kegiatan yang diikuti dari berbagai ekstrakulikuler merupakan faktor yang dapat menjadi penyebab terlibat aktifnya mahasiswa dalam proses perkuliahan.

Yanto et al. (2011b) mengemukakan bahwa pengayaan pengalaman berkorelasi dengan seluruh faktor kompetensi internasional akuntansi. AUSSE (2010) mengemukakan bahwa pengayaan pengalaman tidak berpengaruh terhadap nilai rata-rata secara keseluruhan pada mahasiswa. Penelitian ini mengambil kesimpulan bahwa pengayaan pengalaman memberikan kontribusi dalam membangun kompetensi internasional akuntansi forensik.

AUSSE (2011) mengemukakan bahwa lingkungan belajar yang mendukung merupakan lingkungan belajar yang memungkinkan mahasiswa terlibat aktif dalam kegiatan perkuliahan. Involvement theory juga dapat menjelaskan bahwa fasilitas dan lingkungan belajar yang tersedia akan mempengaruhi kelibatan mahasiswa dalam bidang akademis untuk pembentukan 
kompetensi. Astin and Antonio (2012) mengungkapkan bahwa lingkungan belajar adalah lingkungan nyata yang dilalui mahasiswa selama proses pendidikan, dimana dosen berusaha untuk mengembangkan program pembelajaran guna menghasilkan outcome yang baik.

Mahasiswa merupakan input yang paling penting dari proses terbentuknya outcome dari lingkungan belajar (Yanto et al., 2011a). Hal ini sejalan dengan Thurmond et. al. (2002) yang mengemukakan bahwa lingkungan berhubungan dengan output pendidikan. Ridho (2012) juga mengungkapkan bahwa lingkungan berpengaruh terhadap prestasi belajar mahasiswa. Kemudian AUSSE (2010) mengemukakan juga bahwa lingkungan belajar berpengaruh signifikan terhadap rata-rata nilai secara keseluruhan pada mahasiswa. Yanto et al. (2011b) secara lebih spesifik mengemukakan bahwa lingkungan belajar berpengaruh positif terhadap seluruh faktor kompetensi mahasiswa akuntansi. Dengan demikian secara keseluruhan hipotesis dari penelitian ini adalah:

Faktor dari kelibatan mahasiswa dalam pembelajaran akuntansi berkontribusi dalam pembentukan kompetensi internasional akuntansi forensik pda mahasiswa jurusan Akuntansi.

\section{METODE PENELITIAN}

\section{Populasi, Sampel dan Teknik Pengambilan Sampel}

Populasi dalam penelitian ini adalah mahasiswa akuntansi yang sudah menduduki tingkat akhir pada 12 univesitas di Semarang. Jumlah populasi penelitian ini sebesar 2.429 (BAN-PT, 2014 dan DIKTI, 2014). Teknik multistage sampling digunakan untuk menentukan sampel penelitian ini. Tahap pertama adalah memilih universitas secara random berdasarkan akreditasi jurusan akuntansi. Tahap yang kedua adalah memilih mahasiswa angkatan 2011 dari universitas yang terpilih secara random karena mahasiswa angkatan 2011 yang mayoritas telah menempuh tujuh semester dan telah menempuh hampir seluruh mata kuliah akuntansi. Dari teknik ini terkumpul data dari 218 responden yang diambil dari empat universitas.

\section{Metode Pengumpulan dan Analisis Data}

Penelitian ini menggunakan data primer yang diambil menggunakan metode dokumentasi dan metode kuesioner (Arikunto, 2008). Metode dokumentasi digunakan untuk pengumpulan informasi mengenai jumlah universitas di Semarang dan akreditasi jurusan akuntansi pada universitas di Semarang melalui BAN-PT dan Forlap DIKTI. Sedangkan metode kuesioner digunakan untuk mengumpulkan data dari responden mengenai kelibatan mahasiswa pada pembelajaran akuntansi dan kompetensi internasional akuntansi forensik mahasiswa.

\section{Model Penelitian}

Penelitian ini akan mengidentifikasi hubungan antara faktor dari kelibatan mahasiswa dalam pembelajaran akuntansi (KMPA) dan faktor dari kompetensi internasional akuntansi forensik (KIAF) mengunakan analisis korelasi pearson dan korelasi kanonik. Selanjutnya penelitian ini menguji pengaruh faktor-faktor KMPA terhadap KIAF dengan uji regresi. Dalam menentukan koefisien dari model regresi, penelitian ini menggunakan two tail t-test. Berikut merupakan persamaan regresi dari penelitian ini: 


$$
\begin{aligned}
& \mathrm{ETC}=\beta_{0}+\beta_{1} T A+\beta_{2} B A+\beta_{3} H D M+\beta_{4} P P+\beta_{5} L B+\mathrm{e} \\
& \mathrm{CS}=\beta_{0}+\beta_{1} T A+\beta_{2} B A+\beta_{3} H D M+\beta_{4} P P+\beta_{5} L B+\mathrm{e} \\
& \mathrm{ES}=\beta_{0}+\beta_{1} T A+\beta_{2} B A+\beta_{3} H D M+\beta_{4} P P+\beta_{5} L B+\mathrm{e} \\
& \mathrm{KIAF}=\beta_{0}+\beta_{1} T A+\beta_{2} B A+\beta_{3} H D M+\beta_{4} P P+\beta_{5} L B+\mathrm{e}
\end{aligned}
$$

dimana:

$$
\begin{array}{ll}
\mathrm{ETC} & =\text { essentials traits and characteristics } \\
\mathrm{CS} & =\text { core } \text { skills } \\
\mathrm{ES} & =\text { enhanced skills } \\
\mathrm{TA} & =\text { Tantangan Akademik } \\
\mathrm{BA} & =\text { Belajar Aktif } \\
\mathrm{HDM} & =\text { Hubungan Dosen dengan Mahasiswa } \\
\mathrm{PP} & =\text { Pengayaan Pengalaman } \\
\mathrm{LB} & =\text { Lingkungan Belajar } \\
\mathrm{KIAF} & =\text { Kompetensi Internasional Akuntansi Forensik }
\end{array}
$$

\section{HASIL DAN PEMBAHASAN} Analisis Statistik Deskriptif

Pada tabel 2 menunjukkan ringkasan data yang diperoleh dari responden mengenai faktor dari kelibatan mahasiswa pada pembalajaran akuntansi (KMPA) dan faktor dari kompetensi internasional akuntansi forensik (KIAF). Data yang diperoleh dalam penelitian ini berasal dari instrumen dengan skala likert yang terbagi menjadi lima poin penilaian. Anlisis P-plot menunjukkan bahwa sumbu menyebar di sekitar garis diagonal dan mengikuti arah garis diagonal atau dapat diartikan bahwa model seluruh variabel dependen terdistribusi dengan normal (Ghozali, 2013). Hasil analisis ini memberikan gambaran bahwa rata-rata kompetensi Essential Traits and Characteristics (ETC) sebesar 49.06 (77\%) dari nilai maksimal 64. Rata-rata kompetensi Core Skills (CS) sebesar 46.9 (72\%) dari nilai maksimal 65, dan kompetensi Enhanced Skills (ES) 38.21 (71\%) dari nilai maksimal 54.

Tabel 2. Hasil Analisis Deskriptif

\begin{tabular}{lrrrrrrrrr}
\hline & ETC & CS & ES & KIAF & TA & BA & HDM & PP & LB \\
\hline Mean & 49.06 & 46.90 & 38.21 & 134.17 & 34.45 & 32.86 & 17.60 & 8.78 & 21.57 \\
Std. Deviation & 5.614 & 6.677 & 6.767 & 17.550 & 4.059 & 4.592 & 4.584 & 2.851 & 3.452 \\
Max & 64 & 65 & 54 & 179 & 43 & 45 & 30 & 15 & 30 \\
Min & 37 & 30 & 20 & 94 & 22 & 16 & 7 & 3 & 10 \\
\hline
\end{tabular}

\section{Analisis Korelasi}

Hasil pertama dari analisis ini (Tabel 3) ditemukan bahwa koefisien dari variabel TA, BA, HDM, dan LB memiliki korelasi positif atau searah dengan ETC, CS, ES dengan sig. 0,01 (2-tailed). Dari hasil kedua menunjukkan PP memiliki korelasi positif atau searah dengan ETC dan CS dengan tingkat signifikasi 0,05 (2-tailed). Artinya pada hasil analisis pertama dan kedua menunjukkan jika masing-masing dari TA, BA, HDM, PP, dan LB meningkat maka akan diikuti peningkatan masing-masing dari ETC, CS, ES. Dengan kata lain, ketika kelibatan mahasiswa tinggi maka akan diikuti dengan meningkatnya kompetensi mahasiswa. Sementara hasil ketiga menunjukkan bahwa PP memiliki 
koefisien sebesar 0,106 terhadap ES yang berarti tidak ada korelasi antara kedua variabel tersebut. Hasil analisis korelasi pearson menunjukkan bahwa korelasi antara TA dan ES memiliki koefisien korelasi yang paling besar sebesar 0,570 dibandingkan dengan korelasi dengan variabel lainnya.

Tabel 3. Correlation matrix $(n=218)$

\begin{tabular}{ccccccccc}
\hline & ETC & CS & ES & TA & BA & HDM & PP & LB \\
\hline ETC & 1 & & & & & & & \\
CS & $0.778^{* *}$ & 1 & & & & & & \\
ES & $0.724^{* *}$ & $0.805^{* *}$ & 1 & & & & & \\
TA & $0.502^{* *}$ & $0.487^{* *}$ & $0.570^{* *}$ & 1 & & & & \\
BA & $0.437^{* *}$ & $0.390^{* *}$ & $0.346^{* *}$ & $0.508^{* *}$ & 1 & & & \\
HDM & $0.422^{* *}$ & $0.410^{* *}$ & $0.449^{* *}$ & $0.373^{* *}$ & $0.523^{* *}$ & 1 & & \\
PP & & & 0.160 & $0.197^{* *}$ & $0.258^{* *}$ & $0.438^{* *}$ & 1 & \\
& $0.164^{*}$ & $0.155^{* *}$ & & & & & & \\
LB & $0.322^{* *}$ & $0.321^{* *}$ & $0.269^{* *}$ & $0.475^{* *}$ & $0.479^{* *}$ & $0.385^{* *}$ & $0.306^{* *}$ & 1 \\
\hline
\end{tabular}

\section{Analisis Korelasi Kanonik}

Dalam penelitian ini kelibatan mahasiswa dalam pembelajaran akuntansi (KMPA) memiliki lima faktor yaitu TA, BA, HDM, PP, dan LB. Kemudian kompetensi internasional akuntansi forensik memiliki tiga faktor yaitu ETC, CS, dan ES. Dalam hal ini faktor dianggap sebagai variabel. Seluruh variabel independen dan dependen dianalisis dengan korelasi kanonik. Pada tabel 4 menunjukkan Function 1 (Root No 1) dengan correlation coefficient sebesar 0.65241 yang berarti bahwa covariates variabel kanonik menjelaskan $42.56 \%$ dari kanonikal variabel dependent.

Tabel 4. Eigenvalues and Canonical Correlations

\begin{tabular}{llllll}
\hline Root No. & Eigenvalue & Pct. & Cum. Pct. & Canon Cor. & Sq. Cor \\
\hline 1 & 0.74108 & 89.11830 & 89.11830 & 0.65241 & 0.42564 \\
2 & 0.08677 & 10.43388 & 99.55218 & 0.28256 & 0.07984 \\
3 & 0.00372 & 0.44782 & 100.00000 & 0.06091 & 0.00371 \\
\hline
\end{tabular}

Tabel 5 menunjukkan bahwa variabel dependen ETC memiliki korelasi kanonik sebesar $0.74357>0.5$, CS memiliki korelasi kanonik sebesar $0.83268>0.5$, dan ES memiliki korelasi kanonik $0.97490>0.5$. Penelitian ini menggunakan batas terendah dari koefesien korelasi kanonik sebesar 0.5 (Safitri and Indrasari, 2009), artinya seluruh variabel dependen memiliki korelasi kanonik yang signifikan dengan Canonical variables. Dari hasil analisis ini juga dapat dilihat bahwa koefisien dari korelasi kanonik ES sebesar 0.97490 (Function No 1) merupakan variabel dependen yang memiliki korelasi kanonik paling tinggi dengan variabel kanonikal dibandingkan CS dan ES.

Tabel 5. Correlations Between Dependent and Canonical Variables

\begin{tabular}{lccc}
\hline Dependent & \multicolumn{3}{c}{ Function No. } \\
\cline { 2 - 4 } Factors & 1 & 2 & 3 \\
\hline ETC & 0.85851 & -0.46199 & 0.22255 \\
\hline
\end{tabular}




\begin{tabular}{lccc}
\hline CS & 0.83268 & -0.34489 & -.43324 \\
ES & 0.97490 & 0.18138 & -.12913 \\
\hline
\end{tabular}

Tabel 6 menunjukkan bahwa beberapa covariate dan Canonical variables memiliki korelasi yang signifikan, diantaranya adalah Covariate TA menunjukkan koefisien sebesar 0.89572>0.5, covariate BA menunjukkan koefisien sebesar $0.60629>0.5$, dan Covariate HDM menunjukkan koefisien sebesar 0.71805>0.5. Namun demikian, covariate LB menunjukkan koefisien sebesar 0.71786>0.5. TA, BA, HDM, dan LB berkorelasi signifikan dengan Canonical variables. Dengan kata lain hampir seluruh KMPA secara signifikan berkorelasi dengan KIAF, kecuali covariate PP menunjukkan koefisien sebesar $0.19870<0.5$ yang berarti PP tidak berkorelasi secara signifikan dengan Canonical Variables.

Tabel 6. Correlations between COVARIATES and Canonical variables

\begin{tabular}{lccr}
\hline Covariate & \multicolumn{3}{c}{ CAN. VAR } \\
\cline { 2 - 4 } & 1 & 2 & 3 \\
\hline TA & 0.89572 & 0.00003 & -0.00236 \\
BA & 0.60629 & -0.71346 & 0.32639 \\
HDM & 0.71805 & -0.16520 & -0.15183 \\
PP & 0.19870 & -0.42531 & -0.22298 \\
LB & 0.45963 & -0.56043 & -0.64365 \\
\hline
\end{tabular}

\section{Analisis Regresi}

Keempat model regresi yang digunakan dalam penelitian ini bertujuan untuk mengetahui pengaruh faktor dari KMPA terhadap faktor dari KIAF. Hasil dari model regresi 1 (tabel 10) menunjukkan bahwa faktor dari KMPA secara simultan berpengaruh signifikan terhadap ETC dengan $F_{\text {hitung }}$ sebesar 20.972 ( $p=0.000$ ) dan memiliki koefisien determinasi (Adjusted $R$ Square) sebesar 0.315 (31.5\%). Selanjutnya dari hasil uji t menunjukkan bahwa TA, BA, dan HDM signifikan berpengaruh positif terhadap ETC dengan $t_{\text {hitung }}$ masing-masing sebesar 4.982, 1.987, dan 3.244 dengan tingkat signifikansi $p<0.05$. Sementara itu PP dan LB tidak berpengaruh terhadap ETC karena memiliki tingkat signifikansi $p>0,05$. Hasil uji t ini tidak konsisten dengan hasil analisis korelasi pearson dimana PP (0.164) dan LB (0.322) memiliki korelasi terhadap ETC.

Regresi 1

$\mathrm{ETC}=22.144+0.475 \mathrm{TA}+0.179 \mathrm{BA}+0.285 \mathrm{HDM}-0.094 \mathrm{PP}+0.023 \mathrm{LB}+\mathrm{e}$ $\mathrm{n}=218$

$R^{2}=0.315$ 
Tabel 7. Uji Regresi Dengan Variabel Dependen ETC

\begin{tabular}{lrlrrr}
\hline $\begin{array}{l}\text { Independent } \\
\text { Factor }\end{array}$ & Coefficient & $\begin{array}{l}\text { A priori } \\
\text { Expectation }\end{array}$ & t-statistic & p-value & $\begin{array}{l}\text { VIF- } \\
\text { value }\end{array}$ \\
\hline Intercept & 22.144 & & 7.481 & 0.000 & \\
TA & 0.475 & $\beta_{1}>0$ & 4.982 & 0.000 & 1.503 \\
BA & 0.179 & $\beta_{2}>0$ & 1.987 & 0.048 & 1.730 \\
HDM & 0.285 & $\beta_{3}>0$ & 3.244 & 0.001 & 1.627 \\
PP & -0.094 & $\beta_{4}>0$ & -0.755 & 0.451 & 1.273 \\
LB & 0.023 & $\beta_{5}>0$ & 0.202 & 0.840 & 1.501 \\
\hline
\end{tabular}

Dependent Variable: ETC

*Variabel independen berpengaruh positif terhadap variabel dependen

ANOVA

\begin{tabular}{llllll}
\hline & $D f$ & $S S$ & $M S$ & $F$ & p-value \\
\hline Regression & 5 & 2263.695 & 452.739 & 20.972 & $0.000^{\mathrm{b}}$ \\
Residual & 212 & 4576.530 & 21.587 & & \\
Total & 217 & 6840.225 & & & \\
\hline
\end{tabular}

Hasil dari model regresi 2 (Tabel 8) menunjukkan bahwa faktor dari KMPA secara simultan berpengaruh signifikan terhadap CS dengan $\mathrm{F}_{\text {hitung }}$ sebesar 18.635 $(p=0.000)$ dan memiliki koefisien determinasi (Adjusted $R$ Square) sebesar 0.289 (28.9\%). Selanjutnya dari hasil uji t menunjukkan bahwa hanya TA dan HDM yang secara signifikan berpengaruh positif terhadap CS dengan $t_{\text {hitung }}$ sebesar 4.917 dan 3.394 dengan tingkat signifikansi $p<0.05$. Sementara itu TA, PP, dan LB tidak berpengaruh terhadap ES karena memiliki tingkat signifikansi $p>0,05$

Regresi 2

$\mathrm{CS}=16.610+0.568 \mathrm{TA}+0.116 \mathrm{BA}+0.361 \mathrm{HDM}-0.127 \mathrm{PP}+0.078 \mathrm{LB}+\mathrm{e}$ $\mathrm{n}=218$

$R^{2}=0.289$

Tabel 8. Uji Regresi Dengan Variabel Dependen CS

\begin{tabular}{lrlrl}
\hline $\begin{array}{l}\text { Independent } \\
\text { Factor }\end{array}$ & Coefficient & $\begin{array}{l}\text { A priori } \\
\text { Expectation }\end{array}$ & t-statistic & p-value \\
\hline Intercept & 16.610 & & 4.630 & 0.000 \\
TA & 0.568 & $\beta_{1}>0$ & 4.917 & 0.000 \\
BA & 0.116 & $\beta_{2}>0$ & 1.059 & 0.291 \\
HDM & 0.361 & $\beta_{3}>0$ & 3.394 & 0.001 \\
PP & -0.127 & $\beta_{4}>0$ & -0.842 & 0.401 \\
LB & 0.078 & $\beta_{5}>0$ & 0.578 & 0.564 \\
\hline
\end{tabular}

Dependent Variable: CS

*Variabel independen berpengaruh positif terhadap variabel dependen

ANOVA 


\begin{tabular}{llllll}
\hline & $D f$ & $S S$ & $M S$ & $F$ & p-value \\
\hline Regression & 5 & 2953.918 & 590.784 & 18.635 & $0.000^{\mathrm{b}}$ \\
Residual & 212 & 6721.059 & 31.703 & & \\
Total & 217 & 9674.977 & & & \\
\hline
\end{tabular}

Hasil dari model regresi 3 (Tabel 9) menunjukkan bahwa faktor dari KMPA secara simultan berpengaruh signifikan terhadap ES dengan $F_{\text {hitung }}$ sebesar 29.129 ( $\mathrm{p}=0.000$ ) dan memiliki koefisien determinasi (Adjusted $R$ Square) sebesar $0.393(39,3 \%)$. Selanjutnya dari hasil uji t menunjukkan bahwa TA dan HDM signifikan berpengaruh positif terhadap ES dengan $t_{\text {hitung }} 7.811$ dan 5.265 dengan signifikansi $<0.05$. Akan tetapi PP signifikan berpengaruh negatif terhadap ES dengan $t_{\text {hitung }}$ sebesar -2.062 signifikansi $<0.05$. Sementara itu BA dan LB tidak berpengaruh terhadap ES karena memiliki tingkat signifikansi $>0,05$.

Regresi 3

$\mathrm{ES}=6.593+0.844 \mathrm{TA}-0.060 \mathrm{BA}+0.524 \mathrm{HDM}-0.292 \mathrm{PP}-0.101 \mathrm{LB}+\mathrm{e}$

$\mathrm{n}=218$

$R^{2}=0.393$

Tabel 9. Uji Regresi Dengan Variabel Dependen ES

\begin{tabular}{lclcc}
\hline $\begin{array}{l}\text { Independent } \\
\text { Factor }\end{array}$ & Coefficient & $\begin{array}{l}\text { A priori } \\
\text { Expectation }\end{array}$ & t-statistic & p-value \\
\hline Intercept & 6.593 & & 1.963 & 0.051 \\
TA & 0.844 & $\beta_{1}>0$ & 7.811 & 0.000 \\
BA & -0.060 & $\beta_{2}>0$ & -0.581 & 0.562 \\
HDM & 0.524 & $\beta_{3}>0$ & 5.265 & 0.000 \\
PP & -0.292 & $\beta_{4}>0$ & -2.062 & 0.040 \\
LB & -0.101 & $\beta_{5}>0$ & 1.963 & 0.051 \\
\hline
\end{tabular}

Dependent Variable: ES

*Variabel independen berpengaruh positif terhadap variabel dependen

\begin{tabular}{llllll} 
ANOVA & \multicolumn{5}{l}{} \\
\hline & Df & SS & MS & F & p-value \\
\hline Regression & 5 & 4046.376 & 809.275 & 29.129 & $0.000 \mathrm{~b}$ \\
Residual & 212 & 5889.918 & 27.783 & & \\
Total & 217 & 9936.294 & & & \\
\hline
\end{tabular}

Hasil dari model regresi 4 (Tabel 10) menunjukkan bahwa faktor dari KMPA secara simultan berpengaruh signifikan terhadap KIAF yang merupakan penggabungan dari ETC, CS, dan ES dengan $F_{\text {hitung sebesar } 28.485(\mathrm{p}=0.000) \text { dan }}$ memiliki koefisien determinasi (Adjusted $R$ Square) sebesar 0.402 (40.2\%). Selanjutnya dari hasil uji $\mathrm{t}$ menunjukkan bahwa TA dan HDM signifikan berpengaruh positif terhadap KIAF dengan $t_{\text {hitung }}$ sebesar 6.700 dan 4.510 dengan tingkat signifikansi $p<0.05$. Sementara itu BA, PP, dan LB tidak berpengaruh terhadap KIAF karena memiliki $t_{\text {hitung }}$ masing-masing sebesar 0.883, -1.392, dan $0.001 p>0.05$.

\section{Regresi 4}


$\mathrm{ICAF}=45.347+1.886 \mathrm{TA}+0.236 \mathrm{BA}+1.170 \mathrm{HDM}-0.514 \mathrm{PP}+0.000 \mathrm{LB}+\mathrm{e}$

$\mathrm{n}=218$

$R^{2}=0.402$

Tabel 10. Uji Regresi Dengan Variabel KIAF

\begin{tabular}{lrlrc}
\hline $\begin{array}{l}\text { Independent } \\
\text { Factor }\end{array}$ & Coefficient & $\begin{array}{l}\text { A priori } \\
\text { Expectation }\end{array}$ & t-statistic & $\mathrm{p}$-value \\
\hline Intercept & 45.347 & & 5.183 & 0.000 \\
TA & 1.886 & $\beta_{1}>0$ & 6.700 & 0.000 \\
BA & 0.236 & $\beta_{2}>0$ & 0.883 & 0.378 \\
HDM & 1.170 & $\beta_{3}>0$ & 4.510 & 0.000 \\
PP & -0.514 & $\beta_{4}>0$ & -1.392 & 0.165 \\
LB & 0.000 & $\beta_{5}>0$ & 0.001 & 0.999 \\
\hline
\end{tabular}

Dependent Variable: KIAF

*Variabel independen berpengaruh positif terhadap variabel dependen ANOVA

\begin{tabular}{llllll}
\hline & Df & SS & MS & F & p-value \\
\hline Regression & 5 & 26859.368 & 809.275 & 28.485 & $0.000^{\mathrm{b}}$ \\
Residual & 212 & 39980.008 & 27.783 & & \\
Total & 217 & 66839.376 & & & \\
\hline
\end{tabular}

\section{Pembahasan}

Hipotesis dalam penelitian ini adalah faktor dari kelibatan mahasiswa dalam pembelajaran akuntansi (KMPA) berkontribusi dalam pembentukan kompetensi internasional akuntansi forensik (KIAF) pada mahasiswa jurusan Akuntansi. Hasil analisis korelasi pearson menunjukkan variabel TA, BA, HDM, dan LB memiliki korelasi positif dengan ETC, CS, ES dengan sig. 0,01. Sementara itu PP hanya memiliki korelasi positif atau searah dengan ETC dan CS dengan tingkat signifikasi 0,05 . Hasil ini memiliki sedikit perbedaan dengan penelitian Yanto et al. (2011a) dan Yanto et al. (2011b) yang mengemukakan bahwa seluruh faktor memiliki pengaruh terhadap pembentukan kompetensi mahasiswa akuntansi. Berdasarkan analisis ini, sebagian besar faktor dari KMPA mempunyai hubungan yang cukup bagus dengan faktor KIAF.

Sebagai bahan perbandingan, hasil analisis korelasi kanonik menunjukkan bahwa variabel dependen ETC, CS, dan ES berkorelasi signifikan dengan canonical variable TA, BA, HDM, PP, dan LB. Hasil ini juga sejalan dengan hasil penelitian Yanto et al. (2011a) bahwa faktor dari SE berpengaruh terhadap masing-masing faktor dari kompetensi mahasiswa akuntansi dan juga sesuai dengan Yanto et al. (2010) dan Yanto (2012) yang mengemukakan bahwa pembentukan kompetensi internasional lulusan akuntansi dipengaruhi oleh student engagement. Selanjutnya covariate TA, BA, HDM, dan LB berkorelasi dengan canonical variable ETC, CS, dan ES. Sementara itu covariate PP tidak berkorelasi dengan ETC, CS, dan ES. Hasil ini memiliki sedikit berbeda dengan hasil penelitian Yanto et al. (2011b) yang mengemukakan bahwa seluruh covariate SE berkorelasi dengan Canonical variables dari faktor kompetensi mahasiswa akuntansi. Hasil ini masih sejalan dengan analisis pertama, dimana hampir semua variabel independen mempunyai asosiasi dengan variabel dependen. Variabel PP mempunyai peran yang paling lemah dalam membangun KIAF. Kemungkinan besar kegiatan-kegiatan yang diselenggarakan universitas 
yang berhubungan dengan pengayaan pengalaman, belum banyak berhubungan dengan upaya peningkatan KIAF.

Hasil analisis regresi uji t menunjukkan TA dan HDM berpengaruh terhadap ETC, CS, ES, dan KIAF. Hasil ini sesuai dengan penelitian Yanto et al. (2011b) mengenai kompetensi mahasiswa akuntansi, AUSSE (2010) mengenai TA sebagai faktor dari kelibatan mahasiswa, dan Hambleton (2008) yang mengemukakan bahwa HDM merupakan faktor penting dalam pembentukan kompetensi mahasiswa akuntansi. Hal ini menandakan bahwa tantangan akademik sudah berperan sangat baik dalam membangun KIAF. Hubungan dosen dengan mahasiswa mempunyai kontribusi yang signifikan terhadap semua jenis kompetensi.

Hasil yang kedua menunjukkan BA hanya berpengaruh positif terhadap ETC yang juga sesuai dengan penelitian Yanto et al. (2011b) dan AUSSE (2010). Hasil yang ketiga menunjukkan bahwa PP hanya berpengaruh terhadap ES dengan koefisien negatif dimana hasil ini bertolak belakang dengan penelitian yang dilakukan oleh Yanto et al. (2011b) dan AUSSE (2010) yang mengemukakan bahwa PP tidak berpengaruh terhadap kompetensi mahasiswa akuntansi dan pada nilai rata-rata secara keseluruhan. Sementara itu hasil keempat menunjukkan LB tidak berpengaruh terhadap ETC, CS, ES, dan KIAF yang juga bertolak belakang dengan penelititan yang dilakukan oleh Yanto et al. (2011b), AUSSE (2010), Astin and Antonio (2012), Thurmond et al. (2002), dan Ridho (2012). Dengan kata lain, terdapat dua variabel independen yang perannya masih lemah dalam membangun KIAF yaitu PP dan LB.

Lemahnya peran LB dalam membangun kompetensi KIAF, kemungkinan besar disebabkan oleh lingkungan belajar yang masih belum optimum dalam untuk membangun kompetensi internasional akuntansi forensik. Dalam hal ini, kegiatan-kegiatan LB sbermanfaat untuk membangun kompetensi lain dan memang tidak spesifik tertuju pada KIAF. Kemungkinan kedua adalah model analisis data yang belum sesuai, karena semua variabel independen diberlakukan sama padahal variabel-variabel ini kemungkinan mempunyai peran saling mempengaruhi. Analsis regresi menunjukkan bahwa peran PP tidak signifikan terhadap berbagai kompetensi KIAF, kecuali pengaruh variabel ini terhadap ES yang negatif. Hal ini kemungkinan disebabkan karena kegiatan-kegiatan ekstra kurikuler yang diselenggarakan di kampus tidak seiring dengan peningkatan kompetensi akuntansi forensik. Semakin aktif mahasiswa berpartisipasi dalam kegiatan ekstra kurikuler akan berpengaruh negatih terhadap penguasaan kompetensi internasional akuntansi forensik. Kemungkinan kedua adalah adanya distorsi analisis, karena hasil analisis regresi dengan korelasi baik product moment maupun kanonik memberikan hasil yang berbeda.

Berdasarkan seluruh hasil analisis dalam penelitian ini menunjukkan bahwa mahasiswa sudah mempunyai kompetensi internasional akuntansi forensik seperti yang yang dijabarkan AICPA (Davis et al.,2010). Berdasarkan analisis deskriptif, rata-rata nilai penguasaan kompetensi forensi masih berkisar $70 \%$. Oleh karena itu, universitas, fakultas dan jurusan Akuntansi perlu meningkatkan lagi kompetensi tersebut dengan memodifikasi semua faktor dari KMPA. Kegiatan akademis dan hubungan dosen dengan mahasiswa cukup efektif dalam membangun kompetensi internasional akuntansi forensik. Namun demikian, 
kegiatan pengayaan, belajar aktif, dan lingkungan belajar belum seiring dengan program peningkatan kompetensi internasional akuntansi forensik.

\section{SIMPULAN}

Dari hasil penelitian dan pembahasan dapat diambil kesimpulan kompetensi mahasiswa dalam bidang akuntansi forensik sudah sesuai dengan standar internasional yang ditetapkan oleh AICPA dengan rata-rata skor sekitar $70 \%$. Hampir semua faktor KMPA mempunyai hubungan yang signifikan dengan semua faktor kompetensi internasional akuntansi forensik.

Kontribusi setiap faktor KMPA berbeda-beda. Tantangan akademik mempunyai kontribusi terbesar terhadap semua faktor KIAF diikuti dengan faktor HDM dan BA. Sedangkan faktor PP dan LB tidak mempunyai dampak positif terhadap pembangungan KIAF pada mahasiswa jurusan Akuntansi di kota Semarang. Nonsignifikansi pengaruh faktor LB terhadap faktor KIAF kemungkinan disebabkan karena LB yang diselenggarakan oleh universitas, fakultas, maupun jurusan akuntansi tidak seiring dengan pengembangan KIAF. Kemungkinan kedua adalah bahwa terjadi sedikit distorsi pada analisis pada penelitian ini.

Untuk memeperbaiki kompetensi internasional akuntansi forensik, universitas, fakultas, mapun jurusan akuntansi sebaiknya meningkatkan aktivitas akademik mahasiswa maupun hubungan baik dosen mahasiswa. Lingkungan belajar yang mendukung pembentukan kompetensi akuntansi forensik terus dikembangkan. Demikian juga dengan penyelenggaraan kegiatan yang bertujuan untuk pengayaan pengalaman mahasiswa sebaiknya sesuai dengan arah pengembangan kompetensi akuntansi forensik.

Penelitian berikutnya perlu dilakukan dengan mengukur kompetensi akuntansi forensik secara nyata, bukannya berdasarkan persepsi mahasiswa. Walaupun uji asumsi klasik terhadap analisis regresi cukup bagus, nampaknya terjadi sedikit distorsi analisis. Penggunaan analisis jalur maupun SEM perlu dilakukan untuk mengurangi distorsi analisis.

\section{DAFTAR PUSTAKA}

ACFE. (2012). Using Indicators and Internal Loss Data to Forecast Fraud ACFE European Fraud Conference (pp. 1-17).

AICPA. (2012). Consideration of Fraud in a Financial (pp. 145-185): AICPA.

Ajao, Samuel, O, \& Samuel D. (2013). Application Of Forensic Accounting Technique In Effective Investigation And Detection Of Embezzlement To Combat Corruption In Nigeria. Unique Journal of Business Management, Department of Accounting, 1(4), 65-70

Appleton, J. J., Christenson, S. L., \& Furlong, M. J. (2008). Student Engagement

With School: Critical Conceptual And Methodological Issues $f$ The Construct. Psychology in the Schools, 45(5), 1-18. doi: 10.1002/pits.20303

Arikunto, S. (2008). Prosedur Penelitian Suatu Pendekatan Praktek. Jakarta: Rineka Cipta.

Astin, A. W. (1999). Student Involvement : A Developmental Theory for Higher Education. Journal of College Student Development, 40(5), 518-529. 
Astin, A. W., \& Antonio, A. L. (2012). Assessment for Excellence: The Philosophy and Practice of Assessment and Evaluation in Higher Education: Rowman \& Littlefield Publishers.

AUSSE. (2010). Doing more for learning: enhancing engagement and outcomes: Australasian Survey of Student Engagement: Australasian Student Engagement Report: KMPAR.

AUSSE. (2011). Dispelling Myth: Indigenous Students' engagement with university. Student Engagement Briefing. Melbourne. Accessed from https://www.acer.edu.au/files/AUSSE_Research_Briefing_Vol10.pdf

BAN-PT. (2014). Akreditasi Jurusan Akuntansi S1 from www.banpt.kemdiknas.go.id

Bhasin, M. (2007). Forensic Accounting: A New Paradigm For Niche Consulting. The Chartered Accountant, 1-7.

Bhasin, M. (2013). An Emperical Investigation of The Relevant Skills of Forensic Accountants: Experience Of A Developing Economy. European Journal of Accounting Auditing and Finance Research, 1(2), 11-52.

Christiawan, Y. J. (2002). Kompetensi Dan Independensi Akuntan Publik: Refleksi Hasil Penelitian Empiris. Jurnal Akuntansi \& Keuangan, 4(2), 7992.

Davis, C., Farrell, R., \& Ogilby, S. (2010). Characteristics and Skills of the Forensic Accountant. AICPA, 1-34.

DIKTI. (2014). Pangkalan Data Pendidikan Tinggi, from www.forlap.dikti.go.id

Gbegi, D. O., \& Adebisi, J. F. (2014). Forensic Accounting Skills and Techniques in Fraud Investigation in the Nigerian Public Sector. Mediterranean Journal of Social Sciences, 5(3), 243-252.

Hambleton, K. (2008). The Cognitive and Psychological School Engagement of Young Offenders. University College London, London.

Hardern, G. (1995). Development of Standards of Competence in Accounting. British Accounting Association - Special Interest Group(6).

IFAC. (2010). International Accounting Education Standards Board.

Kavanagh, M. H., \& Drennan, L. (2008). What skills and attributes does an accounting graduate need? Evidence from student perceptions and employer expectations. Accounting and Finance, 48, 279-300. doi: 10.1111/j.1467629x.2007.00245.x

KPK. (2013). Laporan Tahunan KPK Tahun 2013, from http://www.kpk.go.id/id/publikasi/laporan-tahunan

Krueger, A. O. (2002). Globalization in Historical Perspective, from http://www.imf.org/external/ pubs/ft/seminar/2002/global/eng/index.htm

Kuh, G. D. (2009). What Student Affairs Professionals Need to Know About Student Engagement. Journal of College Student Development, 50(6), 683706. doi: 10.1353/csd.0.0099

Kumara, A., \& Harsono. (2005). Interaksi Kelas (Pertama ed.). Yogyakarta: Pusat Pengembangan Pendidikan UGM.

Mehta, G. S., \& Mathur, T. (2007). Preventing Financial Fraud Through 'Forensic Accounting'. The Chartered Accountant, 1575-1580.

Mula, J. (2009). Can Competency Skills for Accounting Students be Internationally Harmonised? An Indonesia Application. University of Southern Queensland, Toowoomba, 1-24. 
Mutmainah, S. (2008). Pengaruh Penerapan Metode Pembelajaran Kooperatif Berbasis Kasus Yang Berpusat Pada Mahasiswa Terhadap Efektivitas Pembelajaran Akuntansi Keperilakuan. 1-27.

Norwani, N. M. (2005). Learning Outcomes at Higher Learning Institutions : Do Institutional Environments. Forum of the Australasian Association for Institutional Research, 42-52.

NSSE. (2009). Assessment for Improvement: Tracking Student Engagement Over Time-Annual Results 2009. National Survey of Student Engagement.

Phipps, M., Phipps, C., Kas, S., \& Higgins, S. (2001). University students ' perceptions of cooperative learning : Implications for administrators and instruvtors. The Journal of Experiential Education, 24(1), 14-21.

Putri, T. R. S., \& Harto, P. (2012). Persepsi Mahasiswa Akuntansi dan Akuntan Pendidik Terhadap Kompetensi Yang Dibutuhkan Lulusan Akuntansi. Diponegoro Journal of Accounting, 1(2), 1-9.

Ridho, M. A. (2012). Pengaruh lingkungan terhadap motivasi belajar dan dampaknya terhadap prestasi belajar siswa kompetensi keahlian audio video smk muh. kutowinangun kebumen. (2), 1-15.

Sadjiarto, A. (1999). Akuntansi Internasional : Harmonisasi Versus Standardisasi. Jurnal Akuntansi \& Keuangan, 1(2), 144-161.

Safitri, D., \& Indrasari, P. (2009). Analisis Korelasi Kanonik Pada Perilaku Kesehatan Dan Karakteristik Sosial Ekonomi Di Kota Pati Jawa Tengah. Media Statistika, 2(1), 39-48.

Singleton, T. W., \& Singleton, A. J. (2006). Fraud Auditing and Accounting Forensic: (Online) John Wiley \& Sons.

Thurmond, V. A., Wambach, K., Conners, H. R., \& Frey, B. B. (2002). Evaluation of Student Satisfaction: Determining the Impact of a Web-Based Environment by Controlling for Student Characteristics. (Online) American Journal of Distance Education, 16.

Tuanakotta, T. M. (2013). Akuntansi Forensik \& Audit Investigatif. Jakarta: Penerbit Salemba Empat.

UVIC. (2007). 2006 National Survey of Student Engagement: Institutional Planning and Analysis.

Weber, J. (2006). Implementing an Organizational Ethics Program in an Academic Environment:the Challenges and Opportunities for the Duquesne University Schools of Business. (65), 23-42. doi: 10.1007/s10551-005-39702

Yanto, H. (2012). Towards International Competence of Indonesian Accounting Undergraduates: a Systems Approach To Identify Inter- Education Process University of Southern Queensland Toowoomba, 1-322.

Yanto, H., Mula, J. M., \& Kavanagh, M. H. (2010). A Conceptual Model For Building International Competencies Of Accounting Graduates of Indonesian Universities. School of Accounting, Economics and Finance, University of Southern Queensland Toowoomba, 1-27.

Yanto, H., Mula, J. M., \& Kavanagh, M. H. (2011a). Developing Student's Accounting Competencies Using Astin's I-E-O Model: An Identification Of Key Educational Inputs Based on Indonesian Student Perspectives. 1-24. 
MUHAMMAD RIZKY GARUDA NUSANTARA BACHRUL ZAKIR HAMZAH \& HERI YANTO/

Kompetensi Internasional Akuntansi Forensik Mahasiswa Akuntansi Di Beberapa Universitas...

Yanto, H., Mula, J. M., \& Kavanagh, M. H. (2011b). Does Student Engagement Matter In Building Students' Accounting Competencies? Evidence From Indonesian Universities. 1-19. 